\title{
CAN NEW PRODUCT SELLING AND INNOVATION IN SALES BE IMPROVED BY USING INTERNAL MARKETING AND EMPOWERMENT?
}

\section{MOGU LI SE PRODAJA NOVOG PROIZVODA I INOVATIVNOST U PRODAJI UNAPRIJEDITI PRIMJENOM INTERNOG MARKETINGA I OSNAŽIVANJA?}

\author{
Market-Tržište \\ Vol. 30, No. 1, 2018, pp. 61-75 \\ UDK 658.811:005.342 \\ DOI http://dx.doi.org/10.22598/mt/2018.30.1.61 \\ Preliminary communication
}

\begin{abstract}
Erik Ružića, Dragan Benazićc
a) Juraj Dobrila University of Pula, Faculty of Economics and Tourism "Dr. Mijo Mirković", Preradovićeva 1/1, 52100 Pula, CROATIA, erik.ruzic@unipu.hr

b) Juraj Dobrila University of Pula, Faculty of Economics and Tourism "Dr. Mijo Mirković", Preradovićeva 1/1, 52100 Pula, CROATIA, dbenazić@unipu.hr
\end{abstract}

\begin{abstract}
Purpose - The purpose of this paper is to investigate the impact of internal marketing and empowerment on new product selling and sales innovativeness. The link between sales innovativeness and new product selling was examined as well.
\end{abstract}

Design/Methodology/Approach - Data was collected through a questionnaire aimed at sales professionals. PLS structural equation modeling was applied to analyze the data.

Findings and implications - The results show that internal marketing (IM) and empowerment positively affect new product selling and sales innovativeness. No link was found between sales innovativeness and new product selling. The current study highlights new relationships among different constructs (e.g. internal marketing, empowerment, new product selling, and innovativeness) in the sales context. Due to the above-mentioned linkages, top management, as well as sales and new product development managers can plan internal marketing activities and empower their salesforce to achieve better new product commercialization and enhance their innovativeness.

\section{Sažetak}

Svrha - Cilj je rada istražiti utjecaj internog marketinga i osnaživanja na prodaju novog proizvoda i prodajnu inovativnost. Isto tako, istražuje se i veza između prodajne inovativnosti i prodaje novog proizvoda.

Metodološki pristup - Podatci su prikupljeni anketnim upitnikom namijenjenim prodajnim profesionalcima. Podatci su analizirani korištenjem PLS modeliranja strukturnih jednadžbi.

Rezultati i implikacije - Rezultati pokazuju da interni marketing (IM) i osnaživanje pozitivno utječu na prodaju novog proizvoda i prodajnu inovativnost. Veza između prodajne inovativnosti i prodaje novog proizvoda nije dokazana. Istraživanje upućuje na odnose među različitim konstruktima (interni marketing, osnaživanje, prodaja novog proizvoda, inovativnost) u području prodaje. Temeljem gore navedenih odnosa, vrhovni prodajni i menadžeri za razvoj novog proizvoda mogu planirati aktivnosti internog marketinga te osnažiti prodajnu silu kako bi na kraju poboljšali komercijalizaciju novog proizvoda i potaknuli svoju inovativnost. 
Limitations - The current study has few limitations. Due to the survey sample size, it was not tested for unobserved heterogeneity. With regard to the link between sales innovativeness and new product selling, it is recommended to include moderator and mediator variables. Other antecedents of new product selling and sales innovativeness should be investigated as well.

Originality - The paper identifies the relationships among constructs in the sales context which, to the best of the authors' knowledge, have not been subject of previous research and have received limited attention in the literature.

Keywords - new product selling, sales innovativeness, internal marketing, empowerment
Ograničenja - Istraživanje ima nekoliko ograničenja. Zbog veličine uzorka $u$ istraživanju nije provedena provjera na neustanovljenu heterogenost. Po pitanju veze između prodajne inovativnosti i prodaje novog proizvoda bilo bi uputno uključiti moderatorske i medijatorske varijable. Druge prethodnice prodaje novog proizvoda i prodajne inovativnosti trebaju također biti istražene.

Doprinos - Rad upućuje na odnose između konstrukata u prodajnom okruženju koji, prema saznanjima autora, nisu bili predmetom prethodnih istraživanja.

Ključne riječi - prodaja novog proizvoda, prodajna inovativnost, interni marketing, osnaživanje 


\section{INTRODUCTION}

Contemporary consumers are highly demanding; hence companies have to develop new products to satisfy their new needs, wants, and expectations. Furthermore, new products and innovations are crucial for corporate sustainable growth, development, and survival (McNally, Akdeniz \& Calantone, 2011; Ahmed \& Rafiq, 2006; Crawford \& DiBenedetto, 2011; van den Berg et al., 2014; Ahearne, Rapp, Hughes \& Jindal, 2010; Fu, Richards, Hughes \& Jones, 2010). Previous studies (Crawford \& DiBenedetto, 2011, p. 8) showed that about $28 \%$ of companies' sales and profit derived from new products. Nevertheless, new product development is associated with high risks and costs (Fu et al., 2010, p. 61), and globalization has made new product development even more challenging (Crawford \& DiBenedetto, 2011, p. 8).

In the new product development (NPD) process, sales force plays an important role, especially in the last stage, i.e. commercialization, whose success highly depends on the sales force and their performance (Ingram, LaForge, Schwepker \&Williams, 2008; Crawford \& DiBenedetto, 2011). Moreover, selling new products is demanding (van den Berg et al., 2014; Manning, Ahearne \& Reace, 2014), so it deserves special attention in sales management.

Today's sales force, as part of the business and in accordance with the current environmental demands, has to contribute to the company's overall innovativeness efforts; not only with high level performance in the last stage, but also by showing innovativeness in the sales department itself (i.e. sales innovativeness). Innovativeness of the sales department (Matsuo, 2009, p. 321; Evans, Landry, Li \& Zou, 2007) represents the degree of flexibility, willingness, and propensity to demonstrate and adopt new problem-solving behaviors by the salesforce. This willingness to be flexible and creative in sales may not only add value, which is highly recommended in contemporary business, but it could be very useful in situations of new product selling. Moreover, innovativeness could be a source of competitive advantage (Matsuo, 2009, p. 321) in regular selling situations.

In order to affect these important outcomes (i.e. new product selling and sales innovativeness), the identification of potential manageable and influencing drivers becomes imperative.

One of the concepts with potential influence on new product selling and sales innovativeness is internal marketing (IM). Specifically, marketing activities conducted in the internal market (i.e. between employees) have a wide range of outcomes. It was suggested that IM impacts, among others, job satisfaction, motivation and innovation development (Ahmed \& Rafiq, 2006). If we take into account, on the one hand, that internal marketing basically means conduct of marketing activities in order to get the most out of employees and, on the other hand, the importance of people in innovations and new product selling as already highlighted above, then the links between these factors are worthy of further investigation.

In new product selling situations, the seller often faces new challenges because there is high pressure from the management to push the new product as well as resistance, or at least lots of questions, from customers to be answered and uncertainties to be solved. These situations require some discretion from employees in certain task-related activities (i.e. empowerment). Therefore, it has been suggested (Ahmed \& Rafiq, 2006) that empowerment generates more effective sales results thanks to better exploitation of sales opportunities and salespeople's better adaptability and faster response to customer needs. Moreover, the above-mentioned salesforce creativity and flexibility, and a new way of problem-solving can be fostered if the employees are allowed (i.e. empowered) to react quickly and according to the situation. This creativity, flexibility, and innovation cannot grow without support from the management and the overall organization that shares power with its employees. Accordingly, the concept of empowerment could also be useful in boosting innovativeness and new product sales.

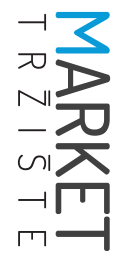

$$
\text { (n) }
$$


Despite their importance as mentioned above, the salesforce roles and sales management specificities do not receive enough attention within NPD literature or within sales literature (Fu et al., 2010; Fu, Jones \& Bolander, 2008). Therefore, the main aim of the present study, which will thus contribute to new insights and knowledge in this insufficiently explored area, is to explore the impact of internal marketing and empowerment on new product selling and sales innovativeness. The link between sales innovativeness and new product selling is explored as well.

To the best of the authors' knowledge, the mentioned relationships have not been studied sufficiently, so the findings of this study will expand the body of knowledge on innovativeness and new product selling by adding new insights in the field.

Based on the demonstrated relationships, the managers (i.e. top manager, sales manager and new product development manager) can plan internal marketing activities and give a stronger impetus to employee empowerment with the final aim to increase sales innovativeness and enhance new product selling.

The paper is divided into seven sections. After the introduction, the second chapter outlines the theoretical background and develops the hypotheses. The following section presents the methodology, i.e. the research instruments, scales, the sample characteristics and data collection. In the fourth chapter, the research results as well as the measurement and structural models are analyzed. The fifth chapter presents the study implications and discussion. The sixth chapter highlights the limitations of the research and provides directions for possible future research. The seventh chapter summarizes the most important conclusions.

\section{LITERATURE REVIEW AND HYPOTHESIS DEVELOPMENT}

The salesforce is embedded in new product development from an early phase on: it plays an important role from the very beginning but is crucial at the time of commercialization of the product when the salesforce predominantly affects customer perceptions of the product and customer buying behavior (Fu et al., 2010). Taking into account the importance of innovation, new product development, and new product selling for long-term company success, as well as potential challenges in these processes and their failure rate (Kuester, Homburg \& Hess, 2012; McNally et al., 2011; Ahearne et al., 2010; Ahmed \& Rafiq, 2006), it becomes crucially important to address the effects of some potentially highly influential antecedents, such as internal marketing and empowerment. The hypothesized relationships are discussed herein.

\subsection{Internal marketing and new product selling}

New product commercialization is connected with growth and company's survival (van den Berg et al., 2014) and is seen as a critical challenge (Kuester et al., 2012). At this point, salespeople, described as a workhorse of the commercialization phase, undertakes personal selling activities that are crucial for success (Crawford \& DiBenedetto, 2011).

Despite its importance, selling new products is often not a well-received task (Fu et al., 2008), which is performed without proper salesperson's commitment and engagement (Ahearne et al., 2010). The success of new product selling depends mostly on the salesperson's attitude toward a new product selling task, his/her willingness to visit new accounts, and on the emphasis put on the stages of personal selling process, especially on the presentation of a new product (van den Berg et al., 2014). These are the components of successful new product selling efforts as well.

In view of the foregoing, the demanding commercialization stage deserves special attention from top and sales managers. Kuester and others (2012, p. 38) argued that for a new product launch to be successful, special attention must be given to internal market (especially manage- 
ment and salespeople). Changes in the sales management mix (e.g. changes in aligning quotas) are not enough (Wotruba \& Rochford, 1995). In line with this, Fu and others (2010, p. 61) claimed that, in new product commercialization, sales managers must increase salespeople's self-efficacy and affect their attitude toward selling the product in order to increase their selling intentions and sales. A changed attitude will impact salespeople's willingness and the level of emphasis on new product presentation. Likewise, they pointed out that a normative approach leads to a decrease in selling intentions.

Moreover, Fu and others (2008) highlighted the need to motivate salespeople during the launch of new products, because their intentions to sell new products are of great importance and are positively linked to success. Ahearne and others (2010) pointed out that, due to importance of new product selling, sales managers tend to overmanage sales personnel by practicing too strict control. In view of the foregoing, application of internal marketing has the potential to address many of the challenges mentioned above.

Although Internal Marketing (IM) has arisen from service sector, this holistic concept with multiple influences finds wider application (Hume \& Hume, 2015; Ahmed \& Rafiq, 2006). Basically, IM means the implementation of marketing activities directed at employees, with special attention paid to providing trainings, management support, effective and timely communication, clear job promotion, and rewarding practices (Wu, Tsai \& Fu, 2013). Thus, IM could help in wider acceptance of the new product selling task through targeted and customized training programs and by armoring salespeople with appropriate knowledge and material connected with the new products. Furthermore, as a non-coercive approach based on employees' needs and wants (Ahmed \& Rafiq, 2006), IM could be the tool that can affect self-efficacy and attitudes without striving to normatively press salesforce. Another potential role could be to avoid over- control, as IM influences peoples' attitudes and behaviors by the internal use of the marketing mix (with a special emphasis on internal communication). It has been suggested that internal marketing affects motivation (Hume \& Hume, 2015), so it could be used to motivate salespeople to sell and to achieve high commitment for new product selling, which derives from strong motivation. Moreover, IM is seen as a tool used in overcoming resistance (Ahmed \& Rafiq, 2006; Varey, 1995), in the particular case, resistance to sell a new product, and it cannot be effective without participative/supportive management and HR practices (Ahmed \& Rafiq, 2006).

While decades have passed since the emergence of the concept, IM is still not widely accepted in practice; according to Wieseke, Ahearne, Lam and van Dick (2009), there are no extant studies on the internal marketing topic.

Based on the above and with the aim to enhance knowledge in the field, we state:

Hypothesis 1: Internal marketing has a positive impact on new product selling.

\subsection{Internal marketing and sales innovativeness}

Innovativeness comprises the extent to which the development of new ideas, novelty, and creativity is encouraged within the company context with the aim to develop new products, processes or some kind of new value (Matsuo, 2009, p. 321). In the sales context (i.e. innovativeness of the sales department), it includes the extent of flexibility and creativity of the salesforce (Matsuo, 2009; Evans et al., 2007).

González Mieres, López Sánchez and Santos Vijade (2012) did not find any direct link between IM activities and improved innovation in their study. Ahmed and Rafiq (2006) pointed out the potential role of internal marketing in innovation development, especially in the fields of organizational culture, structure, process and context, communication with employees, people, key competences, and integration. Likewise, it was suggested that IM could be seen as de-

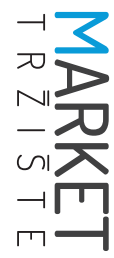




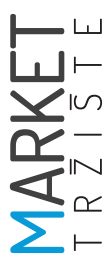

partment integrator, network creator, internal/ external interface and facilitator of the NPD process, as well as a tool in organizational culture shaping (Varey, 1995, p. 49). Moreover, Alamro (n.d.) indicated that the impact of IM activities on the NPD process happened through organizational culture, good communication, reward system, and marketing approach applied in the HR function. While Mosleh, Bahrainzadeh and Bouzanjani (2013, p. 1058) saw IM as comprising three factors (i.e. employee development, internal communication, and reward), the concept in their paper found that employee development has a strong impact on technological innovation, while internal communications and reward systems have no impact. Matsuo (2009, p. 326) highlighted that salespeople can be more innovative if evaluated and rewarded for their behavior and knowledge rather than for their performance.

In view of the foregoing, if implemented, IM affects many organizational aspects and the whole organization, as well as the sales department and its innovativeness. Moreover, IM has the potential to influence the attitude to creativity and flexibility and employee behavior; it comprises evaluation, development, and rewarding employees as well as improved communication and overall integration through the marketing approach (Ahmed \& Rafiq, 2006). Accordingly, it could represent an important tool in developing sales innovativeness.

Taking into consideration customer characteristics and expectations, competitive pressure, and new product commercialization requirements, sales innovativeness is a highly desirable behavior in selling either new or existing products.

Despite the importance of sales innovativeness, there is no extant literature on the topic (Matsuo, 2009). Moreover, it has been noted that there is a limited number of studies related to salesforce and innovation-related activities (van den Berg et al., 2014). To the best of the authors' knowledge, this link between internal marketing and the specific construct of sales innovativeness has not been studied so far.
Based on the above, we hypothesize:

Hypothesis 2: Internal marketing has a positive impact on sales innovativeness.

\subsection{Empowerment and new product selling and sales innovativeness}

Empowerment arises from participative management and employee involvement (Martin \& Bush, 2006, p. 420); it means giving employees influence (Gandz \& Bird, 1996) and discretion over certain task-related activities (Ahmed \& Rafiq, 2006). In their study on sales, Martin and Bush (2006, p. 420) highlighted the notion of empowerment as the willingness to share power between managers and employees and the involvement of subordinates in the decision-making process. The same authors (Martin \& Bush, 2006) outlined that empowerment impacts an employee's attitude toward his/her job. Likewise, it includes the employee's attitude to his/her ability and skills to perform the work, the level of autonomy, freedom, and independence in work environment, and the level of control and influence on the events that happen within the work unit (i.e. department). Empowerment means making the employee more responsible regarding certain aspects of the job. Gandz and Bird (1996, p. 385) stated that empowerment nurtures the employee sense of ownership over their own work.

Overall, empowerment induces positive effects on employees (Spence-Laschinger, Finegan, Shamian \&Wilk, 2004, p. 527). Namely, this discretion affects the employees' motivation (Ahmed \& Rafiq, 2006), productivity, and personal satisfaction (Gandz \& Bird, 1996, p. 385). Ahmed and Rafiq (2006) suggested that empowerment influences job satisfaction, customer orientation, and service quality. Moreover, it affects loyalty and performance (Fulford \& Enz, 1995; Martin \& Bush, 2006). It was also suggested that empowerment leads to reduced role stress, less role ambiguity (Wetzels, de Ruyter \& Bloemer, 2000, p. 66), increased self-efficacy, better adaptability, and faster response to customer needs, less 
waste of time (for example, time spent in consultation with the superior) and quicker service recovery (Ahmed \& Rafiq, 2006), and it also impacts creativity and companies' innovativeness (Çekmecelioğlu \& Özbağ, 2014, p. 10). There are many reasons for empowerment to be implemented, such as highly demanding customers whose needs have to be satisfied quickly, efficiently, and in an accommodating manner (Gandz \& Bird, 1996). Martin and Bush (2006, p. 419) saw empowerment as one of the predictors of customer-oriented selling.

Ahmed and Rafiq (2006) indicated that empowerment, despite a number of positive outcomes, is not convenient in all occasions and for all employees. Fulford and Enz (1995, p. 173) argued that empowerment, besides the mentioned positive outcomes, does not impact strongly on employee work effort and performance. Moreover, there is a number of possible negative consequences of poor empowerment implementation, such as (Gandz \& Bird, 1996, p. 386): change and dislocation, workforce adjustment, irresponsible use of power, and the so-called "empowerment paradox."

In view of the foregoing, empowerment has the potential to positively affect the investigated outcomes (i.e. new product selling and sales innovativeness). Empowerment allows discretion to adapt the task performance and to promptly react to customer needs in a new situation, which leads to easier customization of the service and, consequently, to customer satisfaction, thus providing a competitive advantage to the company. It can be assumed that the demanding task of new product selling can be significantly affected by personal factors, including increased work effort, faster response, customer orientation, performance, adaptability, motivation, personal satisfaction, and less waste of time. Moreover, empowered sales employees could be more inclined to be creative, flexible, and innovative.

To the best of our knowledge, the relationships proposed in the following hypotheses have not been studied sufficiently. With the aim to enlarge the knowledge in the field of sales, we hypothesized as follows:

Hypothesis 3: Empowerment has a positive impact on new product selling.

Hypothesis 4: Empowerment has a positive impact on sales innovativeness.

\subsection{Sales innovativeness and new product selling}

The new product selling task requires tenacious salespeople to be ready to absorb a high rejection rate (Jobber \& Lancaster, 2015). Moreover, they have to be talented, armored with information about the product, and highly capable of presenting the products and convincing the customer (Manning et al., 2014). In new product selling, salespeople face new challenges, new situations, and customers' reactions and often sell products which are not perfect (van den Berg et al., 2014). In such situations, flexibility and creativity of the salesforce could presumably positively impact new product selling.

Despite their crucial role, there is no extant research on the role of salespeople in the process of new product selling (Ahearne et al., 2010), and to the best of the authors' knowledge, there is no research focused on the impact of innovativeness of sales personnel on new product selling. Only Matsuo (2009) in his paper showed that sales innovativeness has positive impact on job satisfaction and job performance.

Based on the above, we state:

Hypothesis 5: Sales innovativeness has a positive impact on new product selling.

\section{METHODOLOGY}

\subsection{Instrument and scales}

Different scales associated with individual constructs were used in the research. The threeitem scale developed by van den Berg and others (2014) was used for the measurement of the new product selling focus. The scale developed by Matsuo (2009) was used in identifying

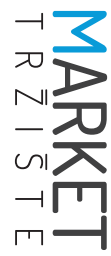




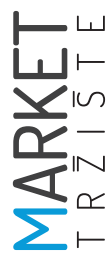

sales innovativeness within the sales department. The empowerment level was measured using the scale designed by Spreitzer (in Martin \& Bush, 2006), and the implementation of internal marketing was defined using the scale developed by Wu and others (2013). All the scales were previously developed and used for the purpose of research among sales force and firstline employees, and their validity and reliability were demonstrated. Accordingly, they were considered suitable for the current study. The scales' items for each construct can be viewed in the Appendix. Demographic questions about the gender, ages, educational background, and years in sales were added to the questionnaire.

All of the scales used were 7-point Likert-type scales (ranging from 1 - strongly disagree to 7 - strongly agree).

\subsection{Sampling}

The survey sample included 101 respondents working as salespeople in different business organizations who fully completed the questionnaire. The questionnaire was sent to 1,000 best companies in Croatia according to the TOP 1000 ranking of added value creators in Croatia, compiled by the business journal Lider. The ranking was published in September 2015, based on the financial data from the 2014 annual report. The questionnaire was compiled in electronic form and sent by email to the enterprises to pass on to their salespeople. In terms of gender, $35.7 \%$ of respondents were male and $64.3 \%$ were female. As to age, $0.9 \%$ of respondents were younger than $26,19.8 \%$ were 26 to 35 years old, $41.6 \%$ from 36 to 45 years old, $24.8 \%$ between 46 and 55 years of age, whereas $12.9 \%$ of respondents were older than 56. In terms of education, $19.8 \%$ of respondents were high school graduates, $63.4 \%$ of respondents held a bachelor or university degree, $16.8 \%$ junior college or higher education degree, whereas $0.07 \%$ of respondents held a master or doctoral degree. As to experience, $26.8 \%$ of respondents had less than 5 years in sales, $27.5 \%$ had 6 to 10 years of experience in sales, $12.7 \%$ of respon- dents worked in sales for 11 to 15 years, while $33 \%$ of respondents had over 15 years of sales experience.

\section{RESEARCH RESULTS}

As this is a research on the development of correlations among several theoretical constructs, the hypotheses were tested according to the PLS-SEM method using the SmartPLS 3 software for data analysis (Ringle, Wende \& Becker, 2015). The PLS-SEM method was chosen over the CBSEM method because of the purpose of the survey, as it is aimed primarily at determining the predictive ability of endogenous constructs, rather than testing the theory (Hair, Ringle \& Sarstedt, 2012). Besides that, the PLS-SEM method provides better results in case of smaller samples and, being a non-parametric method, it is more flexible than the CB-SEM method due to non-observance of the normal distribution rules for indicator variables, as is the case in this research (Table 1) (Hair, Hult, Ringle \& Sarstedt, 2014, p. 19). Finally, the results of the PLS-SEM method can be considered an approximation of CB-SEM results (Reinartz, Haenlein \& Hensler, 2009). Before the analysis, all data were checked as to the presence of outliers. No indicator variable values above $+/-3$ of the standard deviation of the arithmetic mean were identified. In the next section, the authors firstly analyze the psychometric properties of the measurement scales and, afterwards, they test the correlations among individual theoretical constructs within the structural model.

\subsection{Measurement model evaluation}

All theoretical constructs whose correlations are analyzed in the structural model are specified as reflective measurement models (Mode A, Hair et. al., 2014, p. 46). The reflective measurement model was applied because the used indicator variables (items) can be viewed as a representative sample of all the possible items available within the conceptual domain of the construct (Nunnally \& Bernstein, 1994). Fur- 
TABLE 1: Descriptive statistics and item loadings

\begin{tabular}{|c|c|c|c|c|c|c|c|}
\hline & Mean & $\begin{array}{l}\text { Standard } \\
\text { deviation }\end{array}$ & $\begin{array}{c}\text { Excess } \\
\text { kurtosis }\end{array}$ & Skewness & $\begin{array}{c}\text { Item } \\
\text { loadings }\end{array}$ & $\begin{array}{l}\text { St. } \\
\text { dev. }\end{array}$ & T-statistics \\
\hline IM1 & 4.851 & 1.771 & -0.762 & -0.607 & $0.732^{*}$ & 0.051 & 14.409 \\
\hline IM2 & 5.752 & 1.338 & 3.244 & -1.700 & $0.486^{*}$ & 0.125 & 3.879 \\
\hline IM3 & 5.861 & 0.955 & 0.028 & -0.548 & $0.457^{*}$ & 0.106 & 4.306 \\
\hline IM4 & 5.020 & 1.455 & -0.128 & -0.837 & $0.739^{*}$ & 0.051 & 14.528 \\
\hline IM5 & 4.891 & 1.591 & -0.077 & -0.896 & $0.816^{*}$ & 0.033 & 24.868 \\
\hline IM6 & 4.802 & 1.496 & -0.070 & -0.933 & $0.781^{*}$ & 0.042 & 18.817 \\
\hline IM7 & 4.743 & 1.710 & -0.521 & -0.712 & $0.673^{*}$ & 0.068 & 9.894 \\
\hline IM8 & 5.129 & 1.633 & -0.042 & -0.931 & $0.721^{*}$ & 0.060 & 11.991 \\
\hline IM9 & 4.743 & 1.675 & -0.540 & -0.624 & $0.706^{*}$ & 0.061 & 11.537 \\
\hline $\mathrm{IM} 10$ & 4.703 & 1.532 & -0.467 & -0.626 & $0.764^{*}$ & 0.049 & 15.632 \\
\hline IM11 & 5.376 & 1.604 & 0.238 & -1.030 & 0.681 & 0.068 & 10.032 \\
\hline IM12 & 4.069 & 1.946 & -1.374 & -0.074 & 0.645 & 0.076 & 8.546 \\
\hline EMP1 & 6.030 & 1.222 & 5.429 & -2.105 & 0.656 & 0.095 & 6.880 \\
\hline EMP2 & 6.099 & 1.058 & 5.494 & -2.086 & 0.618 & 0.068 & 9.062 \\
\hline EMP3 & 5.812 & 1.175 & 3.522 & -1.634 & 0.789 & 0.053 & 14.910 \\
\hline EMP4 & 6.287 & 0.825 & 15.741 & -2.842 & 0.694 & 0.136 & 5.085 \\
\hline EMP5 & 6.307 & 0.817 & 16.192 & -2.835 & 0.661 & 0.146 & 4.524 \\
\hline EMP6 & 6.109 & 0.866 & 10.937 & -2.255 & 0.574 & 0.170 & 3.380 \\
\hline EMP7 & 5.822 & 1.214 & 4.227 & -1.809 & 0.637 & 0.112 & 5.665 \\
\hline EMP8 & 5.337 & 1.307 & 1.333 & -1.162 & 0.536 & 0.099 & 5.404 \\
\hline EMP9 & 5.149 & 1.360 & 1.068 & -1.065 & 0.672 & 0.090 & 7.488 \\
\hline EMP10 & 4.832 & 1.548 & -0.194 & -0.753 & 0.712 & 0.057 & 12.470 \\
\hline EMP11 & 5.317 & 1.495 & 1.275 & -1.298 & 0.725 & 0.056 & 12.854 \\
\hline EMP12 & 4.842 & 1.565 & 0.133 & -0.881 & 0.735 & 0.057 & 12.858 \\
\hline SINNOV1 & 4.980 & 1.528 & 0.659 & -1.165 & 0.892 & 0.024 & 37.818 \\
\hline SINNOV2 & 4.614 & 1.688 & -0.408 & -0.826 & 0.903 & 0.023 & 39.260 \\
\hline SINNOV3 & 4.762 & 1.517 & 0.217 & -1.023 & 0.819 & 0.046 & 17.870 \\
\hline SINNOV4 & 4.723 & 1.672 & -0.554 & -0.712 & 0.883 & 0.030 & 29.367 \\
\hline SINNOV5 & 4.733 & 1.515 & -0.487 & -0.576 & 0.883 & 0.029 & 30.440 \\
\hline SINNOV6 & 4.119 & 1.831 & -1.331 & -0.227 & 0.742 & 0.055 & 13.413 \\
\hline NPS1 & 5.881 & 1.065 & 3.769 & -1.506 & 0.894 & 0.030 & 29.457 \\
\hline NPS2 & 5.752 & 1.121 & 1.877 & -1.338 & 0.911 & 0.024 & 37.318 \\
\hline NPS3 & 5.624 & 1.319 & 1.369 & -1.193 & 0.870 & 0.032 & 27.050 \\
\hline
\end{tabular}

Source: Authors' calculation

thermore, individual items are interchangeable without threatening content validity of the construct, for instance, item 1 and item 2. Finally, indicator variables represent consequences of individual theoretical constructs (Rossiter, 2002). After specifying the types of the measurement models used, the authors assessed the unidimensionality, as well as the convergent and the discriminant validity of the measurement scales. All indicator variables that had statistically significant outer loadings at the level of $5 \%$ and above 0.4 (Table 1) were excluded from further 
analysis according to the instructions by Hair and others (2014, p. 114). The indicator variables whose item loadings were between 0.4 and 0.7 were excluded from further analysis, if their exclusion led to an increase of CR and AVE parameters above the recommended threshold of 0.8 for CR parameters and 0.5 for AVE parameters. The statistical significance of outer loadings was determined using the bootstrapping procedure with 5,000 subsamples (based on recommendations by Hair et al., 2014, p. 149). Hence, items IM2 and IM3 from the Internal Marketing theoretical construct, and items EMP6, EMP7 and EMP8 from the Empowerment theoretical construct were excluded from further analysis as soon as AVE indicators for the indicated constructs exceeded the value of 0.5. All remaining indicator variables are statistically significant at the level of $5 \%$ and show an acceptable level of item reliability.

Based on Table 2 data, after the elimination of certain indicator variables, it can be concluded that the measurement scales of individual constructs show an acceptable level of internal consistency reliability and convergent validity. Namely, the Cronbach a coefficients are above 0.8 for all theoretical constructs, whereas the Composite Reliability (CR) indicator ranges be- tween 0.90 and 0.94 , i.e. they are higher than the recommended threshold value of 0.8 and lower than 0.95. Furthermore, the Average Variance Extracted (AVE) indicators are above 0.5, ranging from 0.5 to 0.79 for all theoretical constructs.

The Fornell-Larcker criterion (Fornell \& Larcker, 1981) was used to assess discriminant validity. The square roots of AVEs for individual constructs were greater than the correlation between a given construct and each of the other constructs, except for the correlation between the Internal Marketing construct and the Sales Innovation construct. However, as the above-mentioned criterion for the assessment of discriminant validity delivers poorer results in cases when item loadings range between 0.6 and 0.8 (Voorhees, Brady, Calantone \& Ramirez, 2016), as is the case in this study (Table 1), the heterotrait-monotrait ratio (HTMT) of the correlations was applied. This indicator represents the average of the heterotrait-heteromethod correlations (the correlations of indicators across constructs measuring different phenomena) relative to the average of the monotrait-heteromethod correlations (correlations of indicators within the same constructs) (Hensler, Ringle \& Sarstedt, 2015, p. 121). All HTMT indicators are

TABLE 2: Construct, convergent and discriminant validity

\begin{tabular}{|c|c|c|c|c|}
\hline & Empowerment & $\begin{array}{c}\text { Internal } \\
\text { marketing }\end{array}$ & $\begin{array}{c}\text { New prod. } \\
\text { selling }\end{array}$ & Salesinnov. \\
\hline EMPOWERMENT & 0.708 & & & \\
\hline INTERNAL MARKETING & $\begin{array}{l}0.682(0.751)^{*} \\
{[0.595-0.867]}\end{array}$ & 0.732 & & \\
\hline NEW_PROD_SELLING & $\begin{array}{c}0.518(0.588)^{*} \\
{[0.595-0.867]^{* *}}\end{array}$ & $\begin{array}{c}0.545(0.611)^{*} \\
{[0.595-0.867]^{* *}}\end{array}$ & 0.892 & \\
\hline SALESINNOV & $\begin{array}{c}0.681(0.730)^{*} \\
{[0.595-0.867]^{* *}}\end{array}$ & $\begin{array}{c}0.805(0.862)^{*} \\
{[0.595-0.867]^{* *}}\end{array}$ & $\begin{array}{c}0.394(0.430)^{*} \\
{[0.595-0.867]^{* *}}\end{array}$ & 0.856 \\
\hline Cronbach a & 0.874 & 0.903 & 0.872 & 0.926 \\
\hline CR & 0.90 & 0.92 & 0.92 & 0.94 \\
\hline AVE & 0.50 & 0.53 & 0.79 & 0.3 \\
\hline
\end{tabular}


below 0.9, and none of the HTMT bias-corrected confidence intervals contains 1; hence, it can be accepted that the theoretical constructs show discriminant validity.

\subsection{Structural model analysis}

After the evaluation of the reliability and validity of the measurement scales, the next step was to analyze the structural model. The statistical significance of the path coefficients was determined using the bootstrapping method with 5,000 subsamples. The results are showed in Table 3. a statistically significant effect $(p<0.05)$ on the NPS (H3: $\beta=0.338)$ and SINNOV $(H 4: \beta=0.247)$ endogenous constructs. In terms of the effect size, the IM construct has a moderate effect size on NPS $(f 2=0,13)$, while it has a large effect size on SINNOV ( $f 2=0.68)$. The EMP construct has a moderate effect size on the NPS $\left(f^{2}=0.09\right)$ and SINNOV $\left(f^{2}=0.10\right)$ constructs. Hypothesis 5 is rejected as SINNOV has no statistically significant effect on the NPS construct, which is explained in more detail in the next section. All exogenous constructs (IM and EMP) explain the NPS endogenous construct $\left(R^{2}=0.357\right)$ only to a cer-

\section{TABLE 3}

\begin{tabular}{|l|c|c|c|c|c|c|}
\hline Hypothesis & $\begin{array}{c}\text { Original } \\
\text { sample } \\
\text { (0) }\end{array}$ & $\begin{array}{c}\text { Sample } \\
\text { mean } \\
\text { (M) }\end{array}$ & $\begin{array}{c}\text { Standard } \\
\text { deviation } \\
\text { (STDEV) }\end{array}$ & $\begin{array}{c}\text { T Statistics } \\
\text { (|O/STDEV|) }\end{array}$ & $\begin{array}{c}\text { Confidence } \\
\text { interval bias } \\
\text { corrected }\end{array}$ & $\begin{array}{c}\text { Hypothesis } \\
\text { acceptance }\end{array}$ \\
\hline $\begin{array}{l}\text { H1: INTERNAL } \\
\text { MARKETING_ } \\
\text {-> NEW_PROD_ } \\
\text { SELLING }\end{array}$ & $0.519^{*}$ & 0.523 & 0.144 & 3.602 & {$[0.175-0.758]$} & accepted \\
\hline $\begin{array}{l}\text { H2: INTERNAL } \\
\begin{array}{l}\text { MARKETING_-> } \\
\text { SALESINNOV }\end{array}\end{array}$ & $0.636^{*}$ & 0.627 & 0.101 & 6.312 & {$[0.423-0.815]$} & accepted \\
\hline $\begin{array}{l}\text { H3: } \\
\text { EMPOWERMENT } \\
->\text { NEW_PROD_ } \\
\text { SELLING }\end{array}$ & $0.338^{*}$ & 0.342 & 0.122 & 2.768 & {$[0.054-0.545]$} & accepted \\
\hline $\begin{array}{l}\text { H4: } \\
\text { EMPOWERMENT } \\
->\text { SALESINNOV }\end{array}$ & $0.247^{*}$ & 0.264 & 0.100 & 2.466 & {$[0.058-0.448]$} & accepted \\
\hline $\begin{array}{l}\text { H5: SALESINNOV } \\
\text {-> NEW_PROD_ } \\
\text { SELLING }\end{array}$ & -0.254 & -0.261 & 0.154 & 1.644 & $\begin{array}{c}{[-0.541-} \\
0.082]\end{array}$ & rejected \\
\hline
\end{tabular}

$\mathrm{P}<0,05$

Source: authors' calculation

Based on the research results, the hypotheses $\mathrm{H} 1-\mathrm{H} 4$ were accepted, whereas the hypothesis H5 was rejected. The Internal Marketing (IM) construct has a statistically significant effect on the constructs of New Product Selling (NPS) ( $H 1$ : $\beta=0.519)$ and Sales Innovation (SINNOV) $(H 2$ : $\beta=0.636)$. Thus, Empowerment (EMP) has tain extent, but they explain substantially more the variance of the SINNOV construct $\left(R^{2}=0.681\right)$. The structural model has predictive relevance, which was assessed by using the Blindfolding procedure. All endogenous constructs had the $\mathrm{Q}^{2}$ values greater than 0 . 


\section{STUDY IMPLICATIONS AND DISCUSSION}

As previously argued, sales innovativeness and especially new product development's last phase, i.e. new product selling, are important determinants of company success. Moreover, the new product development process involves a number of people within organizations and billions of dollars of investment in economy every year, and innovativeness represents a source of competitive advantage (Matsuo, 2009). Despite such important inputs and outputs, the results of such processes are not satisfactory enough. In addition, the role of salespeople in an NPD process, despite their role as the interface (e.g. boundary spanners) between the company and the customer and their importance in organization's innovative efforts, has not received sufficient attention from researchers and academics. The current study fills a part of this gap or at least it represents a sound contribution to defining the relations among few interconnected aspects, which can contribute to the success of the processes. The present study highlights the importance of new/old approach to human resource management, the philosophy of marketing and a non-coercive approach to employees in order to engage their hearts (not only brains) (Ahmed \& Rafiq, 2006). As already mentioned, thanks to the linkages presented in this research, top management, new product development managers, and sales managers can plan internal marketing activities, apply the market approach to the salesforce (and the whole organization), and put more impetus on empowering them in order to achieve desired outcomes, such as sales innovations and better commercialization of the product. The non-proven impact of sales innovativeness on new product selling can presumably be explained by the low level of sales innovativeness (the mean values are low) within the sales departments of the observed enterprises. In order to demonstrate that link, further research is needed, as explained in detail in the next section.

\section{LIMITATIONS AND FUTURE RESEARCH}

This study has a few limitations that represent opportunities for further research. The limitations relate primarily to the sample, that is, its size and structure. A larger sample would allow obtaining more reliable and valid data and a generalization of the results. Furthermore, the failure to prove $\mathrm{H} 5$, i.e. the indication of adverse impact of SINNOV on NPS, requires further research including moderator and mediator variables (for instance, personal qualities of salespeople, years of experience in sales, level of product innovativeness, and type of buyer). Moreover, the authors did not use a measure of objective sales performance in this research, which is a limitation that should be overcome in future research.

Lastly, due to the small sample size, the authors did not fully test unobserved heterogeneity within the scope of the current research, although the results of the FIMIX procedure suggest the existence of two segments of salesforce of roughly equal size, and in one of these segments the effect of SINNOV on NPS is large $(\beta=0.648)$. Therefore, future research on larger samples should investigate the above phenomenon.

Finally, the influence of other possible antecedents besides internal marketing and empowerment on successful new product selling and sales innovativeness, such as internal knowledge-sharing, should also be investigated. The gained insights could affect the sales results and, consequently, the company's overall success.

\section{CONCLUSION}

Innovation and new product development are conditio sine qua non for contemporary companies. Salespeople as boundary spanners and sales managers as the first among equals are important links in the process. Moreover, salespeople play a key role in the diffusion of innovation (i.e. selling of new products or services) (Ingram et al., 2008), and performed personal selling 
is a key factor for commercialization success (Crawford \& DiBenedetto, 2011). As previously argued, there is a number of challenges in the process, but the stakes are high so it is worthy of further efforts on the part of academics and practitioners alike. The findings suggest that the possible positive effects of internal marketing application within companies result in achieving innovativeness in sales department and new product selling. Today, the 1970s' concept and philosophy could perhaps be revitalized in the complex, yet vital NPD processes for businesses. The notion of empowerment is further highlighted as important in achieving innovativeness and willingness among salespeople to sell new products.

In conclusion, companies which strive to develop and sell new products/services or promote the innovative culture, especially within the sales department, have to approach their own employees using internal marketing (as one of the HRM methods, in addition to the other ones already in use) and sharing power with them. This may be a piece of the puzzle which is currently lacking to achieve better results in innovative efforts.

\section{References}

1. Ahearne, M., Rapp, A., Hughes, D. E., \& Jindal, R. (2010). Managing Sales Force Product Perceptions and Control Systems in the Success of New Product Introductions. Journal of Marketing Research, 47(4), 764-776.

2. Ahmed, P. K., \& Rafiq, M. (2006). Internal Marketing: Tools and Concepts for Customer-Focused Management. Oxford: Butterworth-Heinemann.

3. Alamro (n.d.). The Impact of Internal Marketing on NPD. Available at: https://www.pomsmeetings.org/confpapers/060/060-0339.pdf

4. Çekmecelioğlu, H. G., \& Özbağ, G. K. (2014). Psychological empowerment and support for innovation in Turkish manufacturing industry: Relations with individual creativity and firm innovativeness. Journal of East European Management Studies, 21(1), 10-34.

5. Crawford, M., \& DiBenedetto, A. (2011). New Product Management. 10 ${ }^{\text {th }}$ ed. New York, NY: McGraw-Hill Irwin.

6. Evans, K. R., Landry R. E., Li, P. C., \& Zou, S. (2007). How sales controls affect job-related outcomes: the role of organizational sales-related psychological climate perceptions. Journal of the Academy of Marketing Science, 35(3), 445-459.

7. Fornell, C., \& Larcker, D. F. (1981). Evaluating structural equation models with unobservable variables and measurement error. Journal of Marketing Research, 18(1), 39-50.

8. Fu, F. Q., Richards, K. A., Hughes, D. E., \& Jones, E. (2010). Motivating Salespeople to Sell New Products: The Relative Influence of Attitudes. Journal of Marketing, 74(6), 61-76.

9. Fu, F. Q., Jones, E., \& Bolander, W. (2008). Product Innovativeness, Customer Newness, and New Product Performance: A Time-Lagged Examination of the Impact of Salesperson Selling Intentions on New Product Performance. The Journal of Personal Selling and Sales Management, 28(4), 351-364.

10. Fulford, M. D., \& Enz, C. A. (1995). The Impact Of Empowerment On Service Employees. Journal of Managerial Issues, 7(2), 161-175.

11. Gandz, J., \& Bird, F. G. (1996). The Ethics of Empowerment. Journal of Business Ethics, 15(4), 383-392.

12. González Mieres, S., López Sánchez, J. A., \& Santos Vijade, M. L. (2012). Internal Marketing, Innovation and Performance in Business Services Firms: The Role of Organizational Unlearning. International Journal of Management, 29(4), 403-429.

13. Hair, J. F., Hult, M. T., Ringle, M. C., \& Sarstedt, M. (2014). A Primer on Partial Least Squares Structural Equation Modeling. Boston, MA: Sage Publications Ltd. 
14. Hair, J. F., Ringle, M. C., \& Sarstedt, M. (2012). Partial Least Squares: The better approach to structural equation modeling?. Longe Range Plannig, 45(5/6), 312-319.

15. Hensler, J., Ringle, M. C., \& Sarstedt, M. (2015). A new criterion for assessing discriminant validity in variance-based structural equation modeling. Journal of the Academy of Marketing Science, 43, 115-135.

16. Hume, C., \& Hume, M. (2015). The Critical Role of Internal Marketing in Knowledge Management in Not-for-Profit Organizations. Journal of Nonprofit \& Public Sector Marketing, 27, 23-47.

17. Ingram, T. N., LaForge, R. W., Schwepker, C. H., \& Williams, M. R. (2008). Sales Management: Analysis and Decision Making. $7^{\text {th }}$ ed. London: Routledge

18. Jobber, D., \& Lancaster, G. (2015) Selling and Sales Management. 10 ${ }^{\text {th }}$ ed. Harlow: Pearson Education Limited.

19. Kuester, S., Homburg, C., \& Hess, S. C. (2012). Externally Directed and Internally Directed Market Launch Management: The Role of Organizational Factors in Influencing New Product Success. The Journal of Product Innovation Management, 29(51), 38-52.

20. Manning, G. L., Ahearne, M., \& Reace, B. L. (2014). Selling Today: Partnering to Create Value. $12^{\text {th }}$ ed. Toronto: Pearson Education.

21. Martin, C. A., \& Bush, A. J. (2006). Psychological Climate, Empowerment, Leadership Style, and Customer Oriented Selling: An Analysis of the Sales Manager-Salesperson Dyad. Journal of the Academy of Marketing Science, 34(3), 419-438.

22. Matsuo, M. (2009). The Influence of Sales Management Control on Innovativeness of Sales Departments. The Journal of Personal Selling and Sales Management, 29(4), 321-333.

23. McNally, R. C., Akdeniz, M. B., \& Calantone, R. J. (2011). New Product Development Processes and New Product Profitability: Exploring the Mediating Role of Speed to Market and Product Quality. The Journal of Product Innovation Management, 28(1), 63-77.

24. Mosleh, A., Bahrainzadeh, M., \& Bouzanjani, A. A. (2013). The Effect of Internal Marketing on Technological Innovation in KnowledgeBased Enterprises. Journal of Basic and Applied Scientific Research, 3(5), 1058-1066.

25. Nunnally, J. C., \& Bernstein, I. (1994). Psychometric theory. New York, NY: McGraw-Hill.

26. Reinartz, W., Haenlein, M., \& Hensler, J. (2009). An empirical comparison of the efficacy of covariance-based and variance-based SEM. International Journal of Research in Marketing, 26, 332-344.

27. Ringle, C. M., Wende, S., \& Becker, J-M. (2015). SmartPLS 3. Boenningstedt: SmartPLS GmbH.

28. Rossiter, J. R. (2002). The C-OAR-SE procedure for scale development in marketing. International Journal of Research in Marketing, 19, 305-335.

29. Spence Laschinger, H. K., Finegan, J. E., Shamian, J., \&Wilk, P. (2004). A Longitudinal Analysis of the Impact of Workplace Empowerment on Work Satisfaction. Journal of Organizational Behavior, 25(4), 527-545.

30. van den Berg, W. E., Verbeke, W., Bagozzi, R. P., Worm, L., de Jong, A., \& Nijssen, E. (2014). Salespersons as Internal Knowledge Brokers and New Products Selling: Discovering the Link to Genetic Makeup. The Journal of Product Innovation Management, 31(4), 695-709.

31. Varey, R. J. (1995). Internal Marketing: A Review and Some InterDisciplinary Research Challenges. Journal of Marketing Management, 11, 25-40.

32. Voorhees, C. M., Brady, M. K., Calantone, R., \& Ramirez, E. (2016). Discriminant validity testing in marketing: An analysis, causes for concern, and proposed remedies. Journal of the Academy of Marketing Science, 44, 119-134.

33. Wetzels, M., de Ruyter, K., \& Bloemer, J. (2000). Antecedents and consequences of role stress of retail sales persons. Journal of Retailing and Consumer Services, 7, 65-75.

34. Wieseke, J., Ahearne, M., Lam, S. K., \& van Dick, R. (2009). The Role of Leaders in Internal Marketing. Journal of Marketing, 73(2), 123-145. 
35. Wotruba, T. R., \& Rochford, L. (1995). The Impact of New Product Introductions on Sales Management Strategy. The Journal of Personal Selling and Sales Management, 15(1), 35-51.

36. Wu, C. Y., Tsai, C. C., \& Fu, C. S. (2013). The Relationships among Internal Marketing, Job Satisfaction, Relationship Marketing, Customer Orientation, and Organizational Performance: An Empirical Study of TFT-LCD Companies in Taiwan. Human Factors and Ergonomics in Manufacturing \& Service Industries, 23(5), 436-449.

\section{Appendix 1: Scale Items}

\begin{tabular}{|c|c|c|}
\hline Construct & Code & Item \\
\hline \multirow{12}{*}{$\begin{array}{l}\text { Internal } \\
\text { marketing } \\
\text { (Wu, Tsai \& Fu, } \\
\text { 2013) }\end{array}$} & IM1 & My company provides sufficient training programs \\
\hline & IM2 & Attending the training programs improves my ability to do my job \\
\hline & IM3 & Training sessions help me to understand current and future customer needs \\
\hline & IM4 & Managers often offer guidance in solving job-related problems \\
\hline & IM5 & Two-way information flow across management levels is encouraged \\
\hline & IM6 & $\begin{array}{l}\text { Management encourages the development of innovative strategies, accepting that } \\
\text { some may fail }\end{array}$ \\
\hline & IM7 & I periodically receive feedback from my superior on my job performance \\
\hline & IM8 & I am made aware of the overall policies and goals of my company \\
\hline & IM9 & I am adequately informed about my company's financial position \\
\hline & IM10 & This company has suitable policies for job promotion \\
\hline & IM11 & This is the best company to work for in the industry \\
\hline & IM12 & We get rewarded when a target is achieved \\
\hline \multirow{12}{*}{$\begin{array}{l}\text { Empowerment } \\
\text { (Spreitzer in } \\
\text { Martin \& Bush, } \\
\text { 2006) }\end{array}$} & EMP1 & The work I do is very important to me \\
\hline & EMP2 & My job activities are personally meaningful to me \\
\hline & EMP3 & The work I do is meaningful to me \\
\hline & EMP4 & I am confident about my ability to do my job \\
\hline & EMP5 & I am self-assured about my capabilities to perform my work activities \\
\hline & EMP6 & I have mastered the skills necessary for my job \\
\hline & EMP7 & I have significant autonomy in determining how I do my job \\
\hline & EMP8 & I can decide on my own how to go about doing my work \\
\hline & EMP9 & I have considerable opportunity for independence and freedom in how I do my job \\
\hline & EMP10 & My impact on what happens in my department is large \\
\hline & EMP11 & I have a great deal of control over what happens in my department \\
\hline & EMP & I have significant influence on what happens in my department \\
\hline \multirow{6}{*}{$\begin{array}{l}\text { Sales } \\
\text { Innovativeness } \\
\text { (Matsuo, 2009) }\end{array}$} & SINNOV1 & Our ability to function creatively is respected by the leadership \\
\hline & SINNOV2 & Creativity is encouraged here \\
\hline & SINNOV3 & $\begin{array}{l}\text { Around here, people are allowed to try to solve the same problems in different } \\
\text { ways }\end{array}$ \\
\hline & SINNOV4 & This organization can be described as flexible and continually adapting to change \\
\hline & SINNOV5 & This organization is open and responsive to change \\
\hline & SINNOV6 & The reward system here encourages innovation \\
\hline \multirow{3}{*}{$\begin{array}{l}\text { New product } \\
\text { selling (van den } \\
\text { Berg et. al., 2014) }\end{array}$} & NPS1 & I like to present my customers with our most innovative products \\
\hline & NPS2 & $\begin{array}{l}\text { I like selling products that need me to explain in great detail just what is new and } \\
\text { exciting about them }\end{array}$ \\
\hline & NPS3 & I like to visit new accounts where I have to present what my company is selling \\
\hline
\end{tabular}

